\title{
AN INVESTIGATION ON PARAMETERS FOR MODELING THMS FORMATION
}

\section{S. CHOWDHURY* \\ P. CHAMPAGNE}

Received: 31/10/07

Accepted: 10/12/07

\author{
Department of Civil Engineering \\ Queen's University, Kingston, ON, K7L 3N6, Canada
}

*to whom all correspondence should be addressed: e-mail: Shakhawat@ce.queensu.ca

\begin{abstract}
Reactions between natural organic matter (NOM) and chlorine during disinfecting drinking water form trihalomethanes (THMs) and other chlorinated by products (CBPs), some of which are possible carcinogen to human health. A number of models have been developed to predict THMs formation since the discovery of THMs in drinking waters. A fraction of these models used a total of 22 different parameters while individual models used 3 to 8 parameters. Some existing models incorporated more than one parameter from total organic carbon (TOC), dissolved organic carbon (DOC) and UV absorption capacity at $254 \mathrm{~nm}$ $\left(U_{254}\right)$, while all of these three characterize NOM in water; thus, there exist a possibility of illconditioned coefficient estimation. This paper presents the results of an experimental investigation on different parameters from four water supply systems in Newfoundland, Canada. Strong correlations were found among total organic carbon (TOC), dissolved organic carbon (DOC) and UV absorption capacity at $254 \mathrm{~nm}\left(\mathrm{UV}_{254}\right)$. This study along with the past studies identified $\mathrm{pH}$, temperature and reaction time as significant for THMs formation; however, some existing models ignored these parameters. Although these models have good performance in predicting THMs formation in respective environmental conditions, some models might suffer weakness from mathematical point of view; thus needs to be carefully applied. This study recommends using one parameter from TOC, DOC and $\mathrm{UV}_{254}$ and chlorine dose, $\mathrm{pH}$, temperature and reaction time for future modeling.
\end{abstract}

KEYWORDS: Natural organic matter (NOM), model parameters, trihalomethanes.

\section{INTRODUCTION}

The practice of chlorination for the disinfection of drinking water has been applied for over a century and has resulted in the elimination of most waterborne diseases. The American Water Works Association (AWWA) reported that more than $80 \%$ of water treatment plants in the USA use chlorine as a disinfectant (AWWA, 2000). Similarly, most water treatment plants in Canada, also, use chlorination for disinfection purposes (Health Canada, 2006). For instance more than $90 \%$ of treatment plants in Newfoundland use chlorine as the primary disinfectant (DOE, 2006). An evaluation of the 2001-2004 Drinking Water Surveillance Program (DWSP) shows that 165 treatment plants of $179(92 \%)$ in Ontario use chlorination as their primary disinfectant (MOE, 2006). However, this practice has led to the formation of several chlorinated by-products (CBPs), which is potentially of concern as some of these CBPs have associated cancer risks, as well as other acute and chronic effects on human health (King et al., 2000; Mills et al., 1998; IPCS, 2000). King and Marrett (1996) reported that $14-16 \%$ of bladder cancer in Ontario can be attributed to the CBPs in drinking waters. Minimizing the use of disinfectants could reduce CBPs formation, but would conversely lead to an increase in the incidence of waterborne diseases as a result of an increased exposure to pathogenic microorganisms, and thus, pose a greater risk to human health (Reckow and Singer, 1984; IPCS, 2000).

Chlorine is a very effective disinfectant against waterborne microbiological agents and provides residual protection to inhibit microbiological growth in water distribution systems. Although several disinfectants and disinfection strategies (chlorination, chloramination, chlorine dioxide, granular activated carbon with post chlorination, ozonation, ultraviolet ray 
radiation) are available for this purpose, chlorine remains the most effective and inexpensive disinfectant (Clark et al., 1998; Reiff, 1995; Chowdhury et al., 2007). Trihalomethanes are formed during water treatment when NOM in water reacts with chlorine in the treatment plants and/or residual chlorine in the water distribution systems. A significant amount of research has been performed to characterize THMs formation and their associated health risks (Rodriguez et al., 2000; 2002; Clark et al., 2001; Stevens et al., 1976; Engerholm and Amy, 1983; Amy et al., 1987; Black et al., 1996; Gang et al., 2002; Sohn et al., 2004; Rathbun, 1996; King et al., 2000; Westerhoff et al., 2000). A number of studies have developed models to predict THMs formation, some of which are listed in Table 1. In Table 1, eighteen models are shown to predict THMs formation. Collectively, these models employ 22 different water quality treatment parameters, while individual models typically incorporated 3 to 8 parameters. However, the effect of parameter interactions in the selection of model parameters is typically not considered. Despite strong correlations between DOC, $\mathrm{UV}_{254}$ and TOC, two of these parameters were often used in some of the previous models (Sohn et al., 2004; Black et al., 1996; Amy et al., 1987). More specifically, their combined effects have generally been not considered in some modeling approaches. A few modeling efforts attempted to predict THMs formation on the basis of single parameters such as, NOM, which can be measured as $\mathrm{UV}_{254}$, TOC or DOC (White et al., 2003; Muller, 1998). Some models did not incorporate some critical parameters in THMs formation, such as $\mathrm{pH}$, temperature and reaction time (Kolla, 2004; Rathbun, 1996; Chang et al., 1996). Hence, applicability of these models has often been limited to the site or source water for which the model was initially developed.

In this paper, the effects of individual parameters on THMs formation, their correlations and variability are assessed through experimental investigations using water samples from four different water supply systems in Newfoundland, Canada along with the published literature. The most important parameters have also been identified and recommended for future modeling.

\section{EXPERIMENTAL PROCEDURE}

The surface water samples of four different water supply systems from Newfoundland, Canada were collected throughout September 2004 to August 2005. These are Ferryland, Bonavista, Burin and Clarenville water supply systems, with populations of 607, 4021, 2470 and, 5104 respectively. The water supply systems use source waters from Deep Cove Pond, Long Pond, Big Pond and Lower Shoal Harbor River respectively. The source waters are pretreated in the treatment plants before applying chlorine. The pretreated water samples were collected in 2-litre plastic bottles and refrigerated at $3 \pm 1^{\circ} \mathrm{C}$. The chlorine demands for 1 , $3,7,24,48$ and 120 hours were determined for each of the source waters. The HACH method 8167 and 8021 were followed to determine total and free residual chlorine $(\mathrm{HACH}, 2004)$. Then $1 \mathrm{~L}$ of the water samples were taken to add chlorine. After chlorination and proper mixing, samples were transferred to $120 \mathrm{~mL}$ glass bottles in headspace free condition, capped and placed in the reaction chamber for the designated period. These glass bottles were cleaned and dried in a muffle furnace at $400^{\circ} \mathrm{C}$ for 30 minutes prior to use. The reactions were suspended after designated reaction period by adding $12 \mathrm{mg}$ ammonium chloride following USEPA method 551.1 (USEPA, 1995). Phosphate buffer was used to maintain $\mathrm{pH}$ within 4.8 to 5.5 (USEPA, 1995). Fifty $\mathrm{mL}$ from each of the samples was taken for THMs analysis. The THMs were extracted from these $50 \mathrm{~mL}$ by adding $3 \mathrm{~mL}$ MTBE and $20 \mathrm{~g}$ muffled sodium sulfate (USEPA, 1995). A solution of decafluorobiphenyl was used to achieve final surrogate concentration of $10.0 \mu \mathrm{g} \mathrm{L}^{-1}$. The use of decafluorobiphenyl determined the performance of the analysis. All samples were analyzed within 2 weeks of collection following USEPA method 551.1 (USEPA, 1995).

Two micro liters of the THMs extracts were analyzed using gas chromatography (GC) equipped with a fused silica column $(0.25 \mathrm{~mm} \times 30 \mathrm{~m})$ and micro electron capture detector $(\mu-$ $E C D$ ). The stand-alone methodology to determine trihalomethanes was followed for these analyses. Procedural calibrations were developed using THMs (chloroform, bromodichloromethane, dibromochloromethane, bromoform) standards. Further details of the experimental procedures and calibrations can be found elsewhere (USEPA, 1995). The NOM was measured as $U_{254}$ absorption capacity at $254 \mathrm{~nm}$ wavelengths (UV) using an HP 8453 
Spectrophotometer. The TOC and DOC were measured using a Shimadzu TOC 5000A analyzer. The $\mathrm{CO} 2$ detector was a linearized non-dispersive infrared detector (NDIR). The organic carbon determination was made by injection mode with two injections: the first for determining total carbon and the second to find inorganic carbon. The organic carbon was then calculated as the difference between total and inorganic carbon. For DOC and $U V_{254}$, the samples were filtered using $0.45 \mu \mathrm{m}$ membrane filters and then analyzed. The $\mathrm{pH}$ was measured with model 3000 VWR scientific $\mathrm{pH}$ Meter, which was calibrated using three point calibration $(\mathrm{pH}: 4,7,10)$. The temperature and reaction time were adjusted in the laboratory. The chlorine dose is the administered chlorine in water, while the total chlorine represents chlorine in the combined state and in the free residual form.

\section{PARAMETER INVESTIGATION}

Although 22 parameters have been identified in a number of modeling approaches (Table 1), this paper focuses on the most frequently used parameters: chlorine dose, chlorine demand, total chlorine, TOC, DOC, $\mathrm{UV}_{254}, \mathrm{pH}$, temperature, reaction time and bromide ion concentration. The role of these parameters in THMs formation are briefly discussed in the following sections.

\section{Natural organic matter (NOM)}

Natural organic matter in surface waters include humic substances, hydrophilic acids and organic compounds. The NOM, which is considered to be the most important precursor of THMs formation, has no direct measurement. The NOM can be expressed in terms of surrogate measures, such as TOC, DOC or $\mathrm{UV}_{254}$ (Sung et al., 2000; White et al., 2003; Muller, 1998). Increase in NOM increases THMs formation (Korshin et al., 1997). Figure 1 (i iv) shows the correlation between NOM and THMs formation for the four water sources in Newfoundland. Strong correlations between $\mathrm{UV}_{254}$ and THMs were found in all sources, with coefficients of determination $\left(r^{2}\right)$ ranging between $0.77-0.92$. These findings support in favor of some previously published literature (White et al., 2003; Sung et al., 2000).

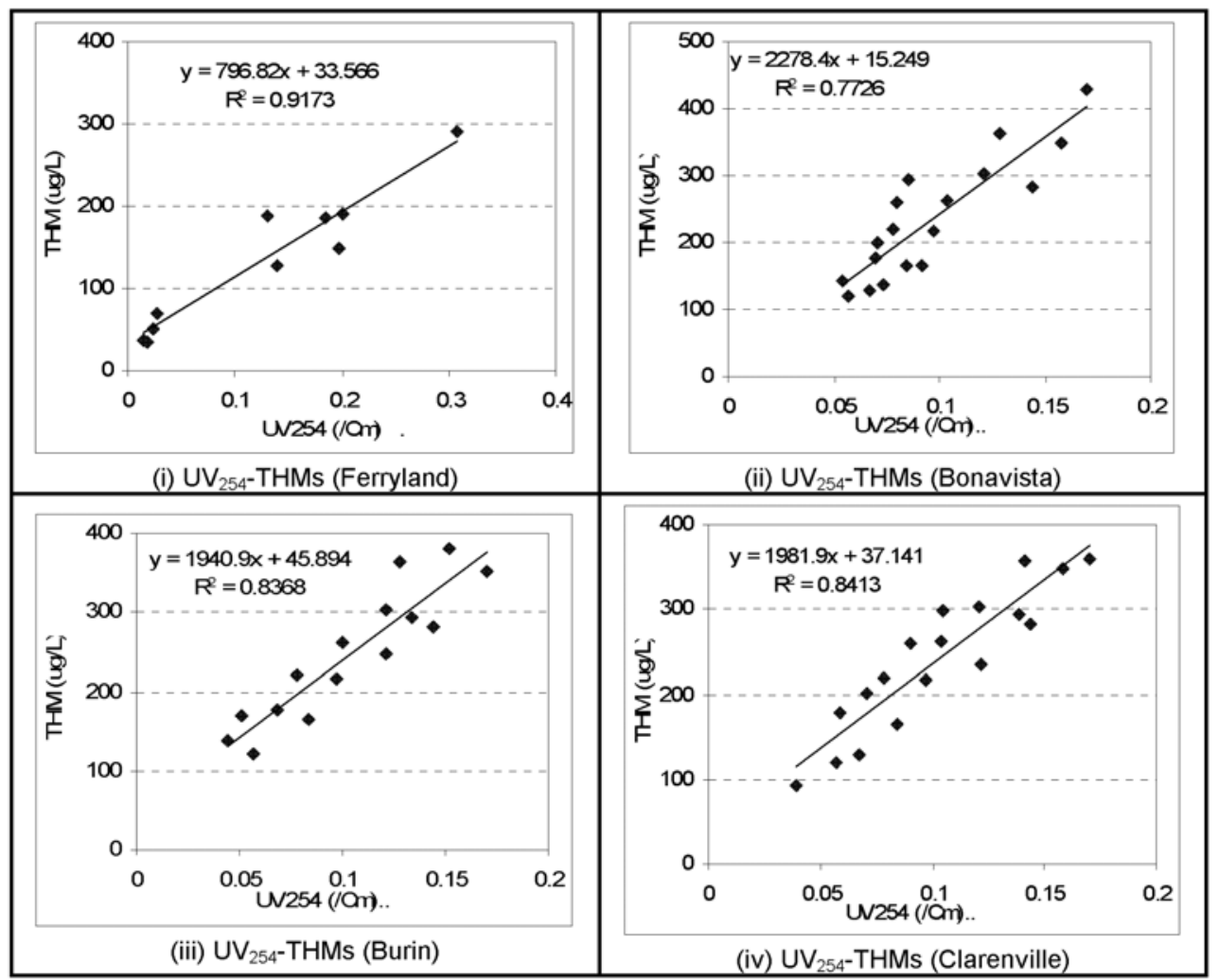

Figure 1. Effects of $U_{254}$ on THMs formation 
pH

The $\mathrm{pH}$ has been found to be correlated with THMs formation. Stevens et al. (1976) performed three experiments using Ohio River water at the Cincinnati treatment plant for different $\mathrm{pH}$ values which exhibited higher THMs formation at higher $\mathrm{pH}$. Depending on the source of organics and chlorination conditions, 30\% to 50\% increase in THMs formation was noted when the $\mathrm{pH}$ was increased from 7 to 11 (Oliver and Lawrence, 1979). The effect of $\mathrm{pH}$ on THMs formation is presented for Ferryland and Clarenville water samples in Figure 2(i-ii). Trihalomethanes formation increase significantly with increasing $\mathrm{pH}$ (Figure 2), which corresponds to results noted in previous studies (Stevens et al., 1976; Oliver and Lawrence, 1979; Kim et al., 2002). In the Ferryland water samples, THMs formation was found approximately $40 \%$ higher when $\mathrm{pH}$ was changed from 6.5 to 8 ; and approximately $25 \%$ higher when $\mathrm{pH}$ was changed from 6.2 to 7.4 in Clarenville water samples. However, at higher $\mathrm{pH}(\mathrm{pH}>8)$, hydrolysis of haloacetic acids and haloacetonitriles takes place, leading to lower total organic halide (Singer, 1994; Krasner et al., 1989).

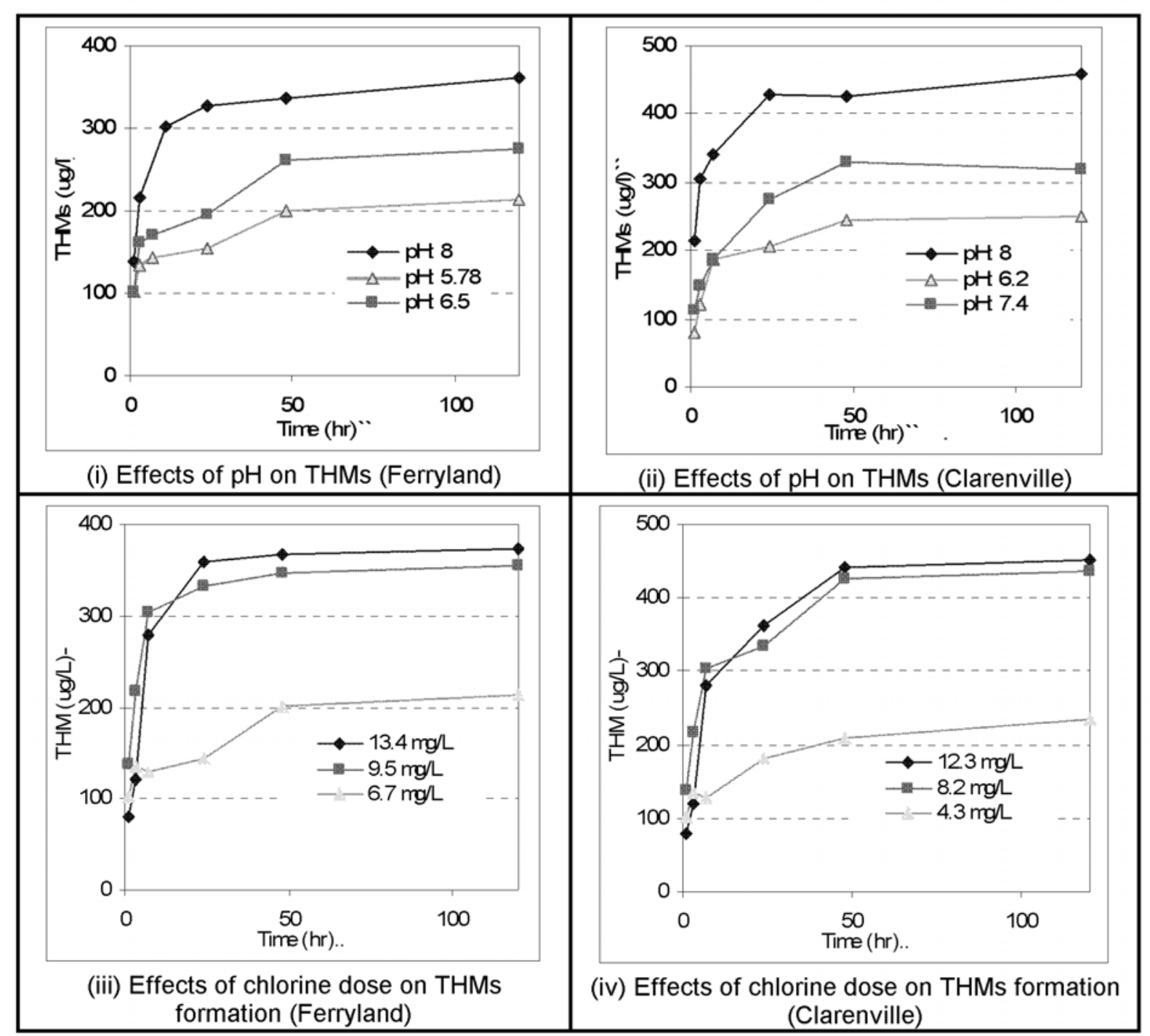

Figure 2. Effects of $\mathrm{pH}$, chlorine dose and reaction time on THMs formation

\section{Reaction time}

Although significant quantities of THMs form rapidly after chlorine addition (Chang et al., 1996), an extended reaction time can also contribute to increased levels of THMs in drinking water (Kim et al., 2002), with the rate of formation decreasing after the rapid reaction phase (Gang et al., 2002). Chang et al. (1996) reported that most of the THMs formation occurred within the first 8 hours of reaction time. Kolla (2004) and Chang et al. (2001) reported no significant increases in THMs beyond 48 hours of chlorination. As it is necessary to provide 
sufficient residual chlorine in water distribution systems to maintain drinking water safe from bacterial contamination (USEPA, 2006; Health Canada, 1996), the practice of maintaining free chlorine residuals could lead to additional THMs in drinking water. The effects of reaction time on THMs formation is illustrated in Figure 2 (i-iv)) using Ferryland and Clarenville water samples exposed to different $\mathrm{pH}$ and chlorine doses, respectively. It can be noted that the rates of THMs formation declined considerably after approximately 7 hours of initial reaction phase (Figure 2 (i-iv)), which correspond to the findings of Kim et al. (2002) and Kolla (2004). It should be noted, however, that some of the CBPs such as haloacetonitriles and haloketones, which are initially formed could decay with time as a result of hydrolysis and reactions with residual chlorine (Nikolaou et al., 1999).

\section{Temperature}

Temperature has also been shown to affect THMs formation in drinking water. Stevens et al. (1976) performed experiments at three different temperatures $\left(3,25\right.$ and $\left.40^{\circ} \mathrm{C}\right)$, constant $\mathrm{pH}$ of 7 and chlorine dose $10 \mathrm{mg} \mathrm{L}^{-1}$ using Ohio River water from the Cincinnati water treatment plant. The formation of THMs was found to be $1.5-2$ times higher at each stage of temperature change. The increase in THMs formation per $10^{\circ} \mathrm{C}$ increase in temperature has been estimated to range between 25-50\% (Engerholm and Amy, 1983). El-Shahat et al. (2001) and Hellur-Grossman et al. (2001) reported higher THMs formation during the summer months than during the winter months, where at higher summer temperatures, reaction rates increased yielding a higher rate of THMs formation. However, the seasonal variability of NOM may play a significant role in this increase in THMs formation.

\section{Chlorine dose}

The amount of chlorine used for disinfection is referred to as the chlorine dose. Figure 2 (iii-iv) shows the effect of chlorine dose on THMs formation for the Ferryland and Clarenville water samples. For these Figures, three chlorine doses were administered (less than breakpoint dose, equal to breakpoint dose and greater than breakpoint dose) for both the water samples, while the breakpoint doses were determined as 9.5 and $8.2 \mathrm{mg} \mathrm{L}^{-1}$ for Ferryland and Clarenville water samples respectively. From Figures 2 (iii-iv), it can be seen that, at the lowest chlorine dosages (less than breakpoint doses), the THMs concentrations were much less than those found at intermediate chlorine dosages (equal to breakpoint doses). However, THMs formation was not found to increase significantly when the chlorine doses were increased further (greater than breakpoint doses). This may be due to the fact that the chlorines beyond breakpoints had insignificant amount of organics to react. This lends partial support to the fact that excess chlorine beyond the breakpoint does not necessarily contribute to significant increases in THMs formation. However, slow reactions of NOM and chlorine in the distribution system may exert partial chlorine demand. The chlorine demand is generally determined to satisfy the actual needs of the water disinfection in the plants and distribution systems (Sung et al., 2000). As such, chlorine demand has been incorporated into certain modeling approaches (Westerhoff et al., 2000; Clark et al., 2001). However, the readily oxidizable substances such as $\mathrm{Fe}^{2+}, \mathrm{Mn}^{2+}$ and $\mathrm{S}^{2-}$ in water can also exhibit a chlorine demand (Gang et al., 2002; MOE, 2004), which may not be associated with THMs formation. Thus, use of chlorine demand may affect the results. The overall amount of chlorine required for oxidation is typically insignificant in comparison to the chlorine required by the NOM (Rodriguez et al., 2002). The chlorine doses used in this controlled study were in the normal operating ranges for Newfoundland $\left(6.7-13.4 \mathrm{mg} \mathrm{L}^{-1}\right.$ for Ferryland; and 4.3-12.3 $\mathrm{mg} \mathrm{L}^{-1}$ for Clarenville water samples); but these may be higher than the normal chlorine doses typically reported in Ontario (mean: $4.06 \mathrm{mg} \mathrm{L}^{-1}$ ). However, elevated chlorine doses are, at times, employed to disinfect water in Newfoundland; consequently, higher levels of THMs in drinking water are generally reported (Kolla, 2004; DOE, 2006). It should be noted that, the application of higher chlorine doses in the treatment of drinking water is not uncommon for drinking water supply systems (MOE, 2004).

\section{Bromide ion concentration}

The presence of bromide ions in chlorinated water results in an increase in the formation of brominated THMs (Barrett et al., 2000). When the ratio of chlorine dosage to bromide ions 
increases, the formation of brominated THMs is favored (Nokes et al. 1999). During chlorination, bromide ions are oxidized to hypobromous acid ( $\mathrm{HOBr}$ ), which reacts more readily with organic precursors than chlorine, forming brominated THMs (Stevens et al., 1976; Singer and Chang, 1989). The combined action of chlorine and hypobromous acid leads to the formation of mixed chloro-/bromo-THMs and other mixed halogenated by-products (Singer and Chang, 1989). To date, the presence of bromide ions has not been found correlated with other water quality parameters (Nokes et al., 1999). But, many studies have not considered their impact in THMs formation modeling (Table 1). This may be attributed to the fact that most surface waters, other than those of coastal regions, do not have significant bromide ions (Black et al., 1996).

\section{Total and Dissolved organic carbon}

Total organic carbon (TOC) and dissolved organic carbon (DOC) are direct measurements of organic content. Increases in TOC generally lead to increase in THMs formation (Arora et al., 1997; Chang et al., 2001). Muller (1998) suggested that the concentration of organic matter could be measured as DOC or UV 254 . Similarly, Korshin et al. (1997) reported that specific UV absorbance (SUVA), a ratio between UV absorbance capacity and DOC, was a good indicator of NOM in water. The SUVA was found correlated with CBPs formation by Barrett et al. (2000) and Krasner et al. (1989). Figure 3 illustrates the correlation between DOC, TOC and THMs formation using Ferryland and Bonavista water samples. In Ferryland water, TOC has been found strongly correlated $\left(r^{2}=0.94\right)$ to THMs (Figure $3(\mathrm{i})$ ), while in Bonavista water TOC exhibited a lower correlation $\left(r^{2}=0.76\right)$ with THMs (Figure 3 (iii)). Dissolved organic carbon is generally more representative of the soluble organic carbon fraction than TOC, and increase in DOC generally led to increase in THMs formation (Muller, 1998; Westerhoff et al., 2000). Figure 3(ii) shows strong correlation between DOC and THMs in Ferryland water $\left(r^{2}=\right.$ $0.92)$, while in Bonavista water, slightly less correlation $\left(r^{2}=0.84\right)$ was observed (Figure 3 (iv)).



Figure 3. Effects of DOC and TOC on THMs formation 
The correlations among TOC, DOC and UV absorbance capacity are presented in Figure 4 for Ferryland and Bonavista water samples. In general, UV-TOC, UV-DOC and DOC-TOC demonstrated strong correlations in Ferryland water with $r^{2}$ values of $0.82,0.97$ and 0.88 , respectively (Figure 4 (i-iii)). Similar correlations $\left(r^{2}\right.$ value of $0.85,0.93$ and 0.83 , respectively) were also found for Bonavista water (Figure 4 (iv-vi)). A number of models have considered TOC or DOC in addition to $\mathrm{UV}_{254}$ modeling THMs formation (Table 1). For instance, Chang et al. (1996) and Black et al. (1996) demonstrated the formation of THMs in relation to TOC, $\mathrm{UV}_{254 \mathrm{~nm}}$ other parameters, while both TOC and $\mathrm{UV}_{254 \mathrm{~nm}}$ represent NOM in water.

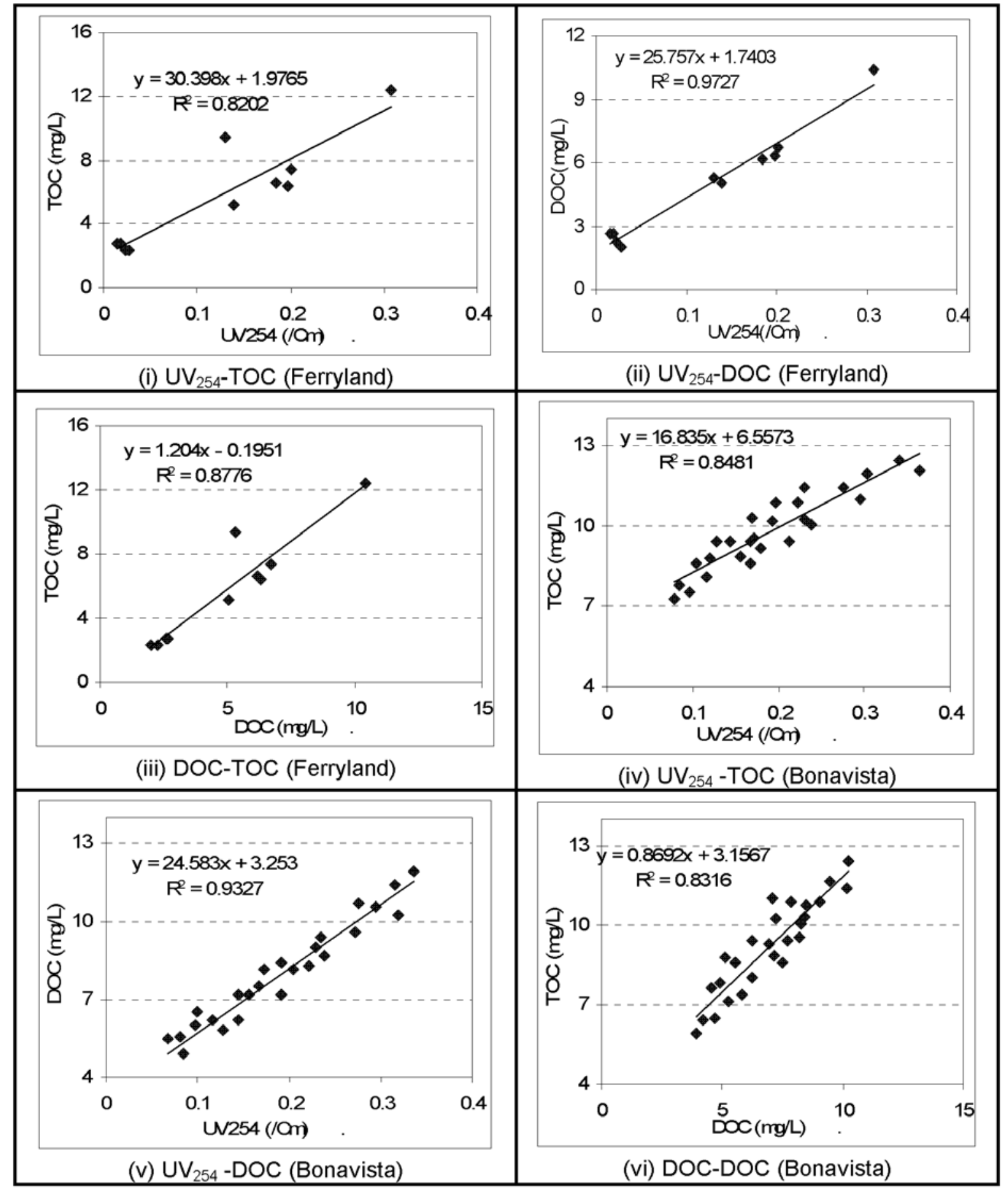

Figure 4. Interactions among parameters 


\section{SUMMARY AND DISCUSSIONS}

In predicting human health risk from exposure to THMs in drinking water, numerical modeling is an alternative approach to complex experimental procedures for determining THMs concentrations in drinking water, which can be expensive and time consuming. However, the accuracy of the predictions and their acceptability are often critical issues because of the inherent variability of the parameters. Existing THMs prediction models present a number of advantages, as well as limitations. The experimental results presented in Figures 1-4 indicate good to strong correlations among the selected water quality parameters for all of the water samples. Differences in correlations could be attributed to the natural variability and environmental conditions at the specific site of the source waters. The general behaviors of the associated parameters can be generalized as follows:

- THMs formation increases with increase in $\mathrm{pH}$, reaction time and NOM

- Reaction rates generally increase with temperature, yielding higher rates of THMs formation.

- The chlorine demand increases with increasing NOM content, which is measured as $\mathrm{UV}_{254}, \mathrm{TOC}$ or DOC, as well as slow reactions in the pipes and pipe materials itself. The TOC, DOC and $U_{254}$ have strong correlations with THMs formation, while TOC, DOC and $U_{254}$ are strongly correlated with each other.

- Bromide ions can be an important factor in the modeling of THMs formation in areas where bromide ion concentrations are high (e.g. coastal areas). The presence of bromide ions leads to the increased formation of brominated THMs resulting in a corresponding decrease in the formation of chlorinated THMs.

The chlorine beyond the actual demand by the NOM in water has insignificant effect on THMs formation. As such, model development requires careful investigation of the chlorine demand exerted by the organic compounds, which are precursors to THMs formation. The results of the research presented herein conducted using water samples from 4 communities in Newfoundland (Canada) recommends that only chlorine demand exerted by the NOM be considered in modeling efforts related to THMs formation. However, determination of actual chlorine demand by the NOM may be difficult due to variability in the distribution systems as well as residence time in the distribution system. In case of drinking water, requirements of chlorine to oxidize the reduced substances is generally insignificant; thus application of chlorine doses may provide safe practices.

The TOC, DOC and $U_{254}$ are strongly correlated with each other and are considered to represent THMs precursors in water. Use of more than one from these parameters as independent modeling parameters may produce ill conditioned coefficient estimation. The THMs formation models those used both $U_{254}$ and TOC need to be carefully explained (Table 1). Reaction time, temperature and $\mathrm{pH}$ have been shown to significantly affect THMs formation. The effect of one or more of these parameters has often omitted in some modeling approaches (Table 1). For instance, temperature was not incorporated in 2, 5, 15; pH was not considered in 4, 13; and reaction time was omitted in 3, 8. The omission of some of these potentially significant parameters in modeling efforts raises the question on models' performance in diverse operating conditions. Although the models presented in Table 1 have shown good predictability when applied to the specific testing locations for which they were developed, the general knowledge gap in terms of understanding parameter correlation, interactions and interdependency could lead to difficulties and unreliable results when the model is applied to other source waters or operational conditions. Hence, further research involving the characterization and correlations of these critical water quality parameters is necessary to improve model predictions of THMs formation and the associated risk to human health as a result of exposure to THMs.

The number of parameters required for the modeling of THMs formation could potentially be reduced to NOM measured as $\mathrm{UV}_{254}$ or $\mathrm{DOC}$, chlorine dose, $\mathrm{pH}$, temperature, reaction time and bromide ion concentrations (in areas where applicable, such as coastal regions). Provision for uncertainty analysis could make the model more flexible in its application and ability to reasonably predict THMs formation in diverse operating conditions. It is often difficult for a mathematical precision-based model to incorporate such natural variability. Comprehensive experimental investigations would be useful in assessing the correlations 
among different model parameters. Models should then consider the interactions of the correlated parameters and verify if the interactions are significant. Similarly, care should be taken to ensure that critical model parameters such as reaction time, $\mathrm{pH}$ and temperature are not either directly or indirectly ignored in future model developments.

Table 1. Partial list of models for chlorinated by-products formation

\begin{tabular}{|c|c|c|c|c|}
\hline No & Author & Model & Parameters & Param \\
\hline 1 & $\begin{array}{l}\text { Amy et al., } \\
(1987)\end{array}$ & $\begin{array}{l}\text { TTHM }=0.031(\text { UVABS } \times \text { TOC })^{0.440} \times \\
(\text { CLDose })^{0.409} \times(\text { RXNTM })^{0.265} \times \\
(\text { Temp })^{1.06} \times(\mathrm{pH}-2.6)^{0.715} \times\left(\mathrm{Br}^{-}+1\right)^{0.0358}\end{array}$ & $\begin{array}{l}\text { TTHM = molar basis total THMs }\left(\mu \mathrm{mol}^{-1}\right) \\
\text { RXNTM = reaction time }(\mathrm{h}) ; \\
\text { CLDose = applied chlorine dose }(\mathrm{mg} \text { as } \\
\left.\mathrm{Cl}_{2} \mathrm{I}^{-1}\right) ; \\
\text { TEMP = temperature }\left({ }^{\circ} \mathrm{C}\right) ; \\
\text { BR = bromide concentration }\left(\mathrm{mg} \mathrm{I}^{-1}\right) ; \\
\text { UVABS = UV absorbance }\left(\mathrm{cm}^{-1}\right) ; \\
\text { PH = }(\mathrm{pH}-2.6) \text { with } 2.6 \text { represented a } \\
\text { statistically determined minimum pH at } \\
\text { which THMs formation }\end{array}$ & 7 \\
\hline 2 & $\begin{array}{l}\text { Lou \& } \\
\text { Chiang, } \\
\text { (1994) }\end{array}$ & $\begin{array}{l}\text { TTHM }=[\mathrm{TTHM}]_{0}+7.01(\mathrm{pH}-2.3)^{0.11} \\
{[\mathrm{NVTOC}]^{1.06}(\mathrm{t})^{0.748}\left[\mathrm{Cl}_{2}\right]^{0.764} \times} \\
\left\{\int_{0}^{\infty}\left(\mathrm{e}^{-0.0393[\mathrm{NVTOC}] \mathrm{t}}\right) \frac{1}{2 \sqrt{\pi \theta \bar{D}}} \exp \left[\frac{(1-\theta)^{2}}{4 \theta \overline{\mathrm{D}}}\right] \mathrm{d} \theta\right\}^{0.764}\end{array}$ & $\begin{array}{l}\text { TTHMo=TTHM in water before } \\
\text { chlorination }\left(\mu \mathrm{g}^{-1}\right) \\
\text { NVTOC = non-volatile organic-carbon } \\
\left(\mathrm{mg} \mathrm{I}^{-1}\right) \\
t=\text { contact time }(\mathrm{h}) \\
\mathrm{Cl}_{2}=\text { post-chlorine dose }\left(\mathrm{mg}^{-1}\right) \\
\theta=\text { dimensionless time } \\
\bar{D}=\text { dimensionless dispersion number. }\end{array}$ & 6 \\
\hline 3 & $\begin{array}{l}\text { Ibarluzea } \\
\text { et al., } \\
\text { (1994) }\end{array}$ & $\begin{array}{l}\mathrm{CHCl}_{3}=10.8+0.04(\mathrm{Flu})+1.16(\mathrm{ph}) \\
+0.12(\mathrm{~T})+1.91(\mathrm{Co})\end{array}$ & $\begin{array}{l}\text { Flu: fluorescence of the raw water }(\%) \\
T=\text { water temperature }\left({ }^{\circ} \mathrm{C}\right) \\
\text { Co = residual chlorine at plant after } \\
\text { chlorination }\left(\mathrm{mg} \mathrm{l}^{-1}\right)\end{array}$ & 4 \\
\hline 4 & $\begin{array}{l}\text { Chang et } \\
\text { al., (1996) }\end{array}$ & $\underset{0.072}{\operatorname{TTHM}}=12.7(\mathrm{TOC})^{0.291}(\mathrm{t})^{0.271}(\mathrm{D})^{-}$ & $\begin{array}{l}\text { TOC }=\text { total organic carbon }\left(\mathrm{mg} \mathrm{l}^{-1}\right) \\
D=\text { chlorine dose }\left(\mathrm{mg} \mathrm{l}^{-1}\right)\end{array}$ & 3 \\
\hline 5 & $\begin{array}{l}\text { Rathbun } \\
\text { (1996) }\end{array}$ & $\begin{array}{l}\text { TTHM }=14.69(\mathrm{pH}-3.8)^{1.01}(\mathrm{D})^{0.206} \\
(\mathrm{UV})^{0.849}(\mathrm{t})^{0.306}\end{array}$ & $U V=$ surrogate measure of NOM $\left(\mathrm{cm}^{-1}\right)$ & 4 \\
\hline 6 & $\begin{array}{l}\text { Black et } \\
\text { al., (1996) }\end{array}$ & $\begin{array}{l}\text { TTHM }=7.21 \mathrm{TOC}^{0.004} \times\left(\mathrm{UV}_{254}\right)^{0.534} \times \\
\left(\mathrm{Cl}_{2} \text { dose-7.6 NH } \mathrm{N}_{3}-\mathrm{N}\right)^{0.224} \times(\mathrm{T})^{0.255} \times \\
\left(\mathrm{Br}^{-}+1\right)^{2.01} \times(\mathrm{t})^{0.480} \times(\mathrm{pH}-2.6)^{.719}\end{array}$ & $\begin{array}{l}U^{U} V_{254}=\text { ultraviolet ray absorption } \\
\text { capacity } \\
\mathrm{NH}_{3}-\mathrm{N}=\text { ammonia nitrogen } \\
\mathrm{Br}=\text { bromide concentration }\end{array}$ & 8 \\
\hline 7 & $\begin{array}{l}\text { Garcia- } \\
\text { Villanova } \\
\text { et al., } \\
(1997)\end{array}$ & TTHM $=f\left(D O C, U V, C l_{2}, B r, p H, T, t\right)$ & $\mathrm{Cl}_{2}=$ chlorine dose & 7 \\
\hline 8 & $\begin{array}{l}\text { Golfinopou } \\
\text { los et al. } \\
\text { (1998) }\end{array}$ & $\begin{array}{l}\text { TTHM }=13.5 \ln (\mathrm{Chla})-14.5(\mathrm{pH})+ \\
+230\left(\mathrm{Br}^{-}\right)-140\left(\mathrm{Br}^{2}\right)^{2}-25.3(\mathrm{~S})+ \\
+110.6(\mathrm{Sp})-6.6(\mathrm{~T} \times \mathrm{Sp})+1.48(\mathrm{~T} \times \mathrm{Cl})\end{array}$ & $\begin{array}{l}\mathrm{S}=\text { dummy variable indicating summer } \\
\text { season; } \\
\mathrm{Sp}=\text { dummy variable indicating spring } \\
\text { season; } \\
\mathrm{Chla}=\text { chlorophyll a }\left(\mathrm{mg} \mathrm{m}^{-3}\right) \\
\mathrm{Cl}=\text { chlorine dose }\left(\mathrm{mg} \mathrm{l}^{-1}\right)\end{array}$ & 7 \\
\hline 9 & $\begin{array}{l}\text { Rodriguez } \\
\text { et al., } \\
(2000)\end{array}$ & $\begin{array}{l}\text { TTHM }=0.044(\mathrm{DOC})^{1.030}(\mathrm{t})^{0.262} \\
(\mathrm{pH})^{1.149}(\mathrm{D})^{0.277}(\mathrm{~T})^{0.668}\end{array}$ & $D O C=$ dissolved organic carbon $\left(\mathrm{mg} \mathrm{l}^{-1}\right)$ & 5 \\
\hline 10 & $\begin{array}{l}\text { Westerhoff } \\
\text { et al., } \\
(2000)\end{array}$ & $\begin{array}{l}\mathrm{THM}_{\mathrm{i}}=\mathrm{b}_{\mathrm{o}}+\mathrm{b}_{1}(\mathrm{DOC})+\mathrm{b}_{2} \\
\left(\mathrm{Cl}_{2} \text { consumed }\right)+\mathrm{b}_{3}\left(\mathrm{Br}_{10 \text { percent }}^{-}\right. \\
\text {incorporated })+\mathrm{b}_{4}(\text { Temperature }) \\
+\mathrm{b}_{5}(\mathrm{pH})+\mathrm{b}_{6}(\mathrm{Time})\end{array}$ & & 6 \\
\hline
\end{tabular}


Table 1. Partial list of models for chlorinated by-products formation (Continued)

\begin{tabular}{|c|c|c|c|c|}
\hline No. & Author & Model & Parameters & Param \\
\hline 11 & $\begin{array}{l}\text { Sung et } \\
\text { al., } \\
(2000)\end{array}$ & $\begin{array}{l}\text { TTHM }=\mathrm{a}\left(\mathrm{OH}^{-}\right) \mathrm{j}\left(\mathrm{C}_{0}\left(1-\mathrm{e}^{-\mathrm{k} \tau}\right)\right)^{\mathrm{m}} \\
\left(\mathrm{UV}_{254}\right)^{\mathrm{n}}(\text { algae })^{\mathrm{p}}\end{array}$ & $\begin{array}{l}\mathrm{OH}^{-}=\text {hydroxide concentration }(\mathrm{f}(\mathrm{pH} \text { and } \\
\text { temperature }))^{\mathrm{m}} \\
\left(\mathrm{C}_{\circ}\left(1-\mathrm{e}^{-\mathrm{k} \tau}\right)\right)^{\mathrm{m}}=\text { chlorine consumed by } \\
\text { the reactions } \\
\mathrm{C}_{0}=\text { initial chlorine concentration (dose) } \\
\tau=\text { travel time } \\
\mathrm{k}=\text { rate constant } \\
\mathrm{UV}_{254}=\text { ultraviolet ray absorption capacity }\end{array}$ & 6 \\
\hline 12 & $\begin{array}{l}\text { Clark et } \\
\text { al., } \\
(2001)\end{array}$ & $\operatorname{TTHM}=\mathrm{D}\left(\mathrm{C}_{\mathrm{A}_{o}}-\left(\frac{\mathrm{C}_{\mathrm{A}_{o}}(1-\mathrm{K})}{1-\mathrm{Ke}^{-\mathrm{ut}}}\right)\right)$ & $\begin{array}{l}\mathrm{C}_{\mathrm{Ao}}=\text { initial chlorine concentration }\left(\mathrm{mg} \mathrm{l}^{-1}\right) \\
t=\text { contact time }(\mathrm{min}) \\
D=\text { dimensionless constant (ratio between } \\
\text { TTHM formed }\left(\mu \mathrm{g}^{-1}\right) \text { to chlorine } \\
\left.\text { consumed }\left(\mathrm{mg} \mathrm{l}^{-1}\right)\right) \\
u=\text { rate constant }\left(\mathrm{min}^{-1}\right) ; \text { depends on } \\
\text { initial concentrations of HOCL to chlorine } \\
\text { demand } \\
\mathrm{K}=\text { ratio between reactants required for } \\
\text { DBPs formation (e.g., HOCL to chlorine } \\
\text { demand) }\end{array}$ & 6 \\
\hline 13 & \begin{tabular}{|l|} 
El-Shahat \\
et al., \\
$(2001)$ \\
\end{tabular} & TTHM $=f\left(P C, C l_{2}, B r^{-}, T, t\right)$ & $\begin{array}{l}\mathrm{PC}=\text { precursor concentration } \\
\mathrm{Br}=\text { bromide ion concentration }\end{array}$ & 5 \\
\hline 14 & $\begin{array}{l}\text { Gang et } \\
\text { al., } \\
(2002)\end{array}$ & $\operatorname{TTHM}=\alpha C_{\circ}\left(\begin{array}{l}1-\mathrm{fe}^{-k_{\mathrm{r}} \mathrm{t}}- \\
(1-f) \mathrm{e}^{-k_{\mathrm{s}} \mathrm{t}}\end{array}\right)$ & $\begin{array}{l}\alpha=\text { TTHM yield coefficient ( }(\text { ratio between } \\
\text { TTHM formed }\left(\mu \mathrm{I}^{-1}\right) \text { to chlorine } \\
\text { consumed }\left(\mathrm{mg} \mathrm{l}^{-1}\right) \\
k_{\mathrm{r}}=1 \mathrm{st} \text { order rate constant for rapid } \\
\text { reactions }\left(\mathrm{h}^{-1}\right) \\
k_{\mathrm{s}}=1 \mathrm{st} \text { order rate constant for slow } \\
\text { reactions }\left(\mathrm{h}^{-1}\right) \\
\mathrm{f}=\text { fraction of chlorine demand attributed } \\
\text { to the rapid reactions } \\
\mathrm{C}_{0}=\text { initial chlorine concentration (dose) }\end{array}$ & 6 \\
\hline 15 & $\begin{array}{l}\text { Kolla, } \\
(2004)\end{array}$ & $\begin{array}{l}\text { THMs }=0.0001(\mathrm{D})^{3.14}(\mathrm{pH})^{1.56} \\
(\mathrm{TOC})^{0.69}(t)^{0.175}\end{array}$ & $D=$ chlorine dose $\left(\mathrm{mg} \mathrm{l}^{-1}\right)$ & 4 \\
\hline 16 & \begin{tabular}{|l|} 
Sohn et \\
al., \\
$(2004)$ \\
\end{tabular} & $\begin{array}{l}\text { TTHM }=10^{-1.385}(\mathrm{DOC})^{1.098} \\
\left(\mathrm{Cl}_{2}\right)^{0.152}(\mathrm{Br})^{0.068}(\mathrm{~T})^{0.669}(\mathrm{pH})^{1.601} \\
(\mathrm{t})^{0.263}\end{array}$ & UVA = surrogate measure of NOM & 6 \\
\hline 17 & \begin{tabular}{|l|} 
Sohn et \\
al., \\
$(2004)$ \\
\end{tabular} & $\begin{array}{l}\text { TTHM }=0.42(\mathrm{UVA})^{0.482}(\mathrm{Cl} 2)^{0.339} \\
(\mathrm{Br})^{0.023}(\mathrm{~T})^{0.617}(\mathrm{pH})^{1.601}(\mathrm{t})^{0.261}\end{array}$ & & 6 \\
\hline 18 & \begin{tabular}{|l|} 
Sohn et \\
al., \\
$(2004)$
\end{tabular} & $\begin{array}{l}\text { TTHM }=0.0283(\mathrm{DOC} * \mathrm{UVA})^{0.0421} \\
(\mathrm{Cl} 2)^{0.145}\left(\mathrm{Br}^{-0}\right)^{0.041}(\mathrm{~T})^{0.614}(\mathrm{pH})^{1.606} \\
(\mathrm{t})^{0.261}\end{array}$ & & 7 \\
\hline
\end{tabular}

\section{CONCLUSIONS}

Experimental investigations on THMs formation model parameters, as well as the advantages, complexities and limitations of available THMs formation prediction models have been discussed in this paper. Existing literature and experimental investigations would appear to indicate that there exists a significant gap with respect to the model parameter selections, as well as the characterization of model parameter correlations and interactions. Parameters including $\mathrm{pH}$, temperature, reaction time and bromide ion concentration have been found to be independent and have significant role in THMs formation. Parameters characterizing organics such as TOC, DOC and $U_{254}$ have been found strongly correlated. There is a scientific need to determine and better understand these relationships. However, the spatial 
and temporal variability of NOM and the difficulties associated with its characterization contribute to the complexity. Chlorine dose is affected by the amount and type of organic matter. This study provides a guideline with respect to model parameter selection and their correlations. The interactions among various correlated parameters also need to be considered and modeling guidelines should be established. The resulting THMs formation model could be applied in and greatly beneficial to future human health risk management studies.

\section{ACKNOWLEDGEMENT}

The first author acknowledges Canada Graduate Scholarship (CGS) from Natural Sciences and Engineering Research Council of Canada (NSERC).

\section{REFERENCES}

Amy G.L, Chadik P.A. and Chowdhury Z.K. (1987) Developing models for predicting trihalomethane formation potential kinetics, JAWWA, 79(7), 89-97.

AWWA (2000) Disinfection Systems Survey Committee Report (May, 2000), Water Quality Division, JAWWA, 9, 24-43.

Barrett S.E., Krasner S.W. and Amy G.L. (2000) Natural organic matter and disinfect ion byproducts: Characterization and control in drinking water. An overview, Oxford University Press, NY.

Black B.D., Harrington G.W. and Singer P.C. (1996) Risks by improving organic carbon removal, JAWWA, 88(6), 40-52

Chang E.E., Chao S.H., Chian P.C. and Lee J.F. (1996) Effects of chlorination on THMs formation in raw water, Toxicological and Environmental Chemistry, 56, 211-225.

Chang E.E., Chiang P.C., Ko Y.W. and Lan W.H. (2001) Characteristics of organic precursors and their relationship with disinfect ion by-products, Chemosphere, 44, 1231-1236.

Chowdhury S., Champagne P. and Husain T. (2007) Fuzzy approach for selection of drinking water disinfectants, J Water SRT-Aqua, 56(2), 75-93.

Clark R.M., Adams J.Q., Sethi V. and Sivaganesan M. (1998) Control of microbial contaminants and disinfect ion by-products for drinking water in the US: cost and performance, $J$ Water SRT-Aqua, 47(6), 255-265.

Clark R.M., Thurnau R.C., Sivaganesan M. and Ringhand P. (2001) Predicting the formation of chlorinated and brominated by-products, Journal of Environ. Engineering, 127(6), 493-501.

DOE (2006) Department of Environment, Newfoundland, Water Resources Management (Available online: http://www.env.gov.nl.ca/Env/Env/waterres/Surfacewater/THM/THM_ Distrib_Graph.asp

El-Shahat M.F., Abdel-Halim S.H. and Hassan G.A. (2001) Factors Influencing the Formation of Trihalomethanes in Drinking Water Treatment Plants, Bull. Environ. Contam. Toxicol., 67, 549553

Engerholm, B.A., and Amy, G.L. (1983) A predictive model for chloroform formation from humic acid, JAWWA, 75(8), 418-423.

Gang D.D., Segar R. L. Jr., Clevenger T.E. and Banerji S.K. (2002) Using chlorine demand to predict THM and HAA9 formation, JAWWA, 94(10), 76-86.

Garcia-Villanova R.J., Garcia C., Gomez J.A., Garcia M. P. and Ardanuy R. (1997) Formation, Evaluation and Modelling of Trihalomethanes in the drinking water of $a$ town: $I$. at the municipal treatment utilities, Water Research, 31(6), 1299-1308.

Golfinopoulos S.K., Xilourgidis N.K., Kostopoulou M.N. and Lekkas T.D. (1998) Use of a multiple regression for predicting trihalomethane formation, Water research, 32(9), 2821-2829.

$\mathrm{HACH}$ (2004) HACH method 8021 and 8167 for determination of Free residual chlorine and total chlorine (Website address: http://www.hach.com/)

Health Canada (2006) Guidelines for Canadian Drinking Water Quality, Sixth edition.

Hellur-Grossman L., Manka J., Lamoni-Relis B. and Rebhun M. (2001) THM, haloacetic acids and other organic DBPs formation in disinfect ion of bromide rich Sea of Galilee (Lake Kinneret) water, Water Science and Technology: Water Supply, 1(2), 259-266

Ibarluzea J.M., Goni F. and Santamaria J. (1994) Trihalomethanes in water supplies in the San Sebastian area, Spain, Bull. Environ.Contam. Toxicol., 52(3), 411-418.

IPCS (2000) International Programme on Chemical Safety; Disinfectants and disinfectant byproducts, Environmental Health Criteria 216.

Kim J., Chung Y., Shin D., Kim M., Lee Y., Lim Y. and Lee D. (2002) Chlorination by-products in surface water treatment process, Desalination, 151, 1-9. 
King W.D. and Marrett L.D. (1996) Case-control study of bladder cancer and chlorination by products in treated water (Ontario, Canada), Cancer Causes and Controls, 7,596-604

King W.D., Marrett L.D. and Woolcott C.G. (2000) Case-Control Study of Colon and Rectal Cancers and Chlorination By-products in Treated Water. Cancer Epidemiology, Biomarkers and Prevention, 9, 813-818.

Kolla R.B. (2004) Formation and Modeling of disinfect ion by-products in Newfoundland Communities, Masters Thesis; Memorial University of Newfoundland, NL, Canada.

Korshin G.V., Li C-W., Benjamin M.M. (1997) Monitoring the properties of natural organic matter through UV spectroscopy. Evaluation of a constant theory, Water Research, 31(7), 1987-95.

Krasner S.W., Mcguire M.J., Jacangelo J.J. (1989) The occurrence of disinfection by-products in U.S. drinking water, JAWWA, 81, 41-53.

Lou J.C. and Chiang P.C. (1994) A study of trihalomethanes formation in a water distribution system, Hazardous Materials, 11(2), 333-343.

Mills C.J., Bull R.J., Cantor K.P., Reif J., Hrudey S.E. and Huston P. (1998) Health Risks of Drinking Water Chlorination By-products: Report of an Expert Working Group, Chronic Diseases in Canada, 19(3), 91-102.

MOE (2006) Drinking Water Surveillance Program (DWSP) summary report for the years 20002004 on 179 municipal drinking water supply systems in Ontario. Ministry of Environment, Ontario, Canada.

Muller U. (1998) THM in distribution system, Water Supply, 16(3/4),121-131.

Nikolaou A.D., Kostopoulou M.N., Lekkas T.D. (1999) Organic By-Products of Drinking water Chlorination, Global Nest: the Int. J., 1(3), 143-156.

Nokes C.J., Fenton E. and Randall C.J. (1999) Modelling the formation of brominated trihalomethanes in chlorinated drinking waters, Water Research, 33(17), 3557-3568.

Oliver B.G., and Lawrence S. (1979) Haloforms in drinking water: A study of precursors and precursor removal. JAWWA, 71(3), 161-163.

Rathbun R.E. (1996) Regression equations for disinfection by-products for the Mississipi, ohio and Missouri rivers, Sci. Total Environ., 191, 235-244.

Reckow D.A., Singer P.C. (1984) The removal of organic halide precursors by preozonation and alum coagulation, JAWWA, 76,151-157.

Reiff F.M. (1995) Balancing the chemical and microbial risks in the disinfection of drinking water supplies in developing countries, Assessing and managing health risks from drinking water contamination: approaches and applications. IAHS publication No 233. Rome symposium. 343 pp.

Rodriguez M.J., Serodes J., Morin M. (2000) Estimation of water utility compliance with trihalomethane regulations using a modelling approach, Aqua-Colchester, 49(2), 57-73.

Rodriguez M., Milot J., Serodes J.B. and Pacaud A. (2002) Estimation of bench-scale chlorine decay in drinking water using nth-order kinetic and back propagation Neural Network Models, Water Qual. Res. J. of Canada, 37(3), 613-635

Singer P.C., and Chang S.D. (1989) Research Report; Impact of ozone on the removal of particles, TOC and THM precursors. AWWA Research Foundation, Denver, CO.

Singer C. (1994) Control of Disinfection by-products in drinking water. Journal of Environmental Engineering, 120(4), 727-744.

Sohn J., Amy G., Cho J., Lee Y. and Yoon Y. (2004) Disinfectant decay and disinfection byproducts formation model development: chlorination and ozonation by-products, Water Research, 38, 2461-2478.

Stevens A.A., Slocum C.J., Seeger D.R. and Robeck C.B. (1976) Measurement of THM and precursor concentration changes, JAWWA, 68, 546-554.

Sung W., Matthews B.R., O'Day K. and Horrigan K. (2000) Modeling DBP formation, JAWWA, 92(5), 53-63.

USEPA (1995) Determination of Chlorination Disinfection By-products in Drinking Water By LiquidLiquid Extraction and Gas Chromatography with Electron-Capture Detection. Method 551.1, Office of Research and Development, Cincinnati, Ohio 45268, USA.

USEPA (2006) National Primary Drinking Water Regulations: Stage 2 Disinfectants and Disinfection Byproducts Rule: Final Rule. Federal Register, 71(2)

Westerhoff P., Debroux J., Amy G.L. Gatel D., Mary V. and Cavard J. (2000) Applying DBP models to full-scale plants, JAWWA, 92(3), 89-102.

White D.M., Garland D.S., Narr J. and Woolard C.R. (2003) Natural organic matter and DBP formation potential in Alaskan water supplies, Water Research, 37, 939-947. 